\title{
Modern wheat semi-dwarfs root deep on demand: response of rooting depth to drought in a set of Swiss era wheats covering 100 years of breeding
}

\author{
Cordula N. Friedli $\cdot$ Samuel Abiven $\cdot$ Dario Fossati $\cdot$ Andreas Hund $(\mathbb{C}$
}

Received: 19 July 2018/Accepted: 19 March 2019/Published online: 4 April 2019

(C) The Author(s) 2019

\begin{abstract}
Breeding for enhanced rooting depth and root biomass in deeper soil layers is a promising strategy to adapt wheat (Triticum aestivum L.) plants to drought periods. We evaluated (1) the extent of indirect selection of root traits during the last century of wheat breeding and (2) how it affected the variety performance under well-watered conditions compared to gradually developing drought stress. Fourteen bread wheat genotypes covering 100 years of Swiss wheat breeding were grown in $1.6 \mathrm{~m}$ tall columns in the greenhouse under well-watered and drought conditions. Root parameters, such as rooting depth and root biomass and above ground parameters were determined at flowering and maturity. Rooting depth showed a negative trend in response to year of release
\end{abstract}

Electronic supplementary material The online version of this article (https://doi.org/10.1007/s10681-019-2404-7) contains supplementary material, which is available to authorized users.

C. N. Friedli · A. Hund $(\bowtie)$

Institute of Agricultural Sciences, ETH Zurich,

Universitaetstr. 2, 8092 Zurich, Switzerland

e-mail: andreas.hund@usys.ethz.ch

S. Abiven

Soil Science and Biogeochemistry Unit, Department of Geography, University of Zurich, Winterthurerstr. 190, 8057 Zurich, Switzerland

D. Fossati

Agroscope, Route de Duillier 50, CP 1012, 1260 Nyon 1, Switzerland under well-watered conditions but not under early water stress. Modern varieties responded with enhanced root allocation to deeper soil layers. Consequently, rooting depth was positively correlated with plant height at well-watered conditions but not under early water stress. Considerable genetic variation for rooting depth among modern varieties indicates that the trait is selectable without strong alteration of plant height. We conclude that modern varieties adjusted rooting depth to water demand.

Keywords Breeding - Drought - Rooting depth · Semi-dwarf · Wheat

\section{Introduction}

The 'Green Revolution' enabled a strong increase of wheat (Triticum aestivum L.) yield by using modern agricultural technologies. The introgression of reduced height genes $(R h t)$ in wheat genotypes was the breakthrough in wheat breeding and resulted in high-yielding semi-dwarf wheat varieties that responded to increased fertilizer inputs without the effect of lodging (Dalrymple 1985). In France, 63\% of the bread wheat yield increase can be attributed to genetic improvement (Brancourt-Hulmel et al. 2003). The global annual cereal yields increased between 1961 and 2007 from 877 Mt to 2351 Mt, but must rise 
to $4000 \mathrm{Mt}$ in 2050 in order to meet the demand predicted by the FAO (Tester and Langridge 2010). This means that the past annual yield increase of $32 \mathrm{Mt}$ $\mathrm{a}^{-1}$ need to be enhanced by $37 \%$ to $44 \mathrm{Mt} \mathrm{a}^{-1}$ (Tester and Langridge 2010).

Although wheat yield still increases due to selection, a yield stagnation has been observed since 1990 for several countries in Europe due to altered climate conditions such as drought during stem elongation or heat stress during grain filling (Brisson et al. 2010). Rain fed wheat production in many areas of the world is dependent on stored soil moisture to buffer periods without precipitation. For example, monthly precipitation between May and August in the Swiss plateau is above $100 \mathrm{~mm}$ (MeteoSchweiz 2016), thus usually supplies enough water in an average year. Under such conditions, crops access more than $50 \%$ of their water from the top $0.3 \mathrm{~m}$ of the soil (Oberholzer et al. 2017). However, in dry years water extraction depth increased down to $0.85 \mathrm{~m}$ (Oberholzer et al. 2017). Therefore, efficient water uptake from deeper soil layers is desirable, even under environments with ample precipitation in average years. Crops of the next generation will have to cope with strong fluctuations in precipitation pattern, even in environments with sufficient precipitation. Climate models predict changing patterns for precipitation frequency, amount and intensity (IPCC 2013). Based on future scenarios, wet regions will become wetter and dry regions drier (Sun et al. 2007). Water scarcity and lack of nutrients are among the most limiting factors for plant growth (Lynch 2007). The change in precipitation patterns for Switzerland is predicted to result in higher temperatures with an increased risk of drought periods during summer (Holzkamper et al. 2015). Therefore, locally adapted varieties should be evaluated if they have the potential to utilize stored soil water in cases of prolonged drought periods.

Breeding for deeper roots is probably the most prominent strategy to avoid drought in climates, where deep soil water is available during the main cropping season (Wasson et al. 2012; Manschadi et al. 2006). For example, Manschadi et al. (2006) showed that an increased root length in deeper soil layers supports more water extraction during grain filling and therefore an increase in yield. Wasson et al. (2014) suggested additionally a redistribution of lateral root density from the surface to the depth in combination with a greater radial hydraulic conductivity. Root parameters are not directly selected by breeders and the indirect effect of their selection on root architecture is not well studied yet. Some authors found reduced root length and root biomass weights in modern wheat varieties compared to their tall ancestors (Wojciechowski et al. 2009; Elazab et al. 2016; Waines and Ehdaie 2007; Aziz et al. 2017). In other studies, modern varieties had an increasing or similar amount of roots in deeper soil layers (Hurd 1974; Chloupek et al. 2006) and while some studies observed no effect (Lupton et al. 1974; Cholick et al. 1977). Some studies found differences in the root-shoot ratio between modern and tall old wheat varieties, e.g. Aziz et al. (2017), Qin et al. (2012) and Siddique et al. (1990) found decreasing root-shoot ratio in modern wheat varieties compared to old genotypes. Water capture from soil did not increase in 50 years of single-cross maize breeding in the US corn-belt, leaving the question, how to adapt breeding programs to improve water capture (Reyes et al. 2015).

In the present study, we used a set of 14 bread wheat genotypes covering the last 100 years of Swiss wheat breeding progress. The varieties were evaluated in the greenhouse in $1.6 \mathrm{~m}$ tall growth columns and drought stress during either the stem elongation or grain filling was induced. The aim of the study was to evaluate (1) the extent of indirect selection of root traits during the last century of wheat breeding and (2) how it affected the variety performance under well-watered conditions compared to gradually developing drought stress. We hypothesized that wheat breeding within the last 100 years under climatic conditions of the Swiss Plateau did not alter root biomass and root depth distribution, under optimal nor under water limited conditions.

\section{Materials and methods}

\section{Platform}

This experiment was conducted on the deep root observation platform (DROP) (Fig. 1) in a greenhouse at the ETH research station Lindau-Eschikon, Switzerland. The DROP provides the possibility to observe both above and below ground biomass together during plant growth. To achieve this, the platform was divided into an upper part (Fig. 1a) 
allowing the access to the above ground biomass and a lower part (Fig. 1b) to access the root system.

Above ground, each double row of columns was bordered by growth containers $(2.50 \mathrm{~m} \times 0.12 \mathrm{~m} \times$ $0.13 \mathrm{~m}$ ) with border plants of spring wheat to simulate a canopy density similar to field conditions (Fig. 1a). Aisles (0.50 m wide) between the rows allowed access for watering. The roots were growing in acrylic plastic columns (Plexiglas ${ }^{\circledR}, 1.6 \mathrm{~m}$ in height,

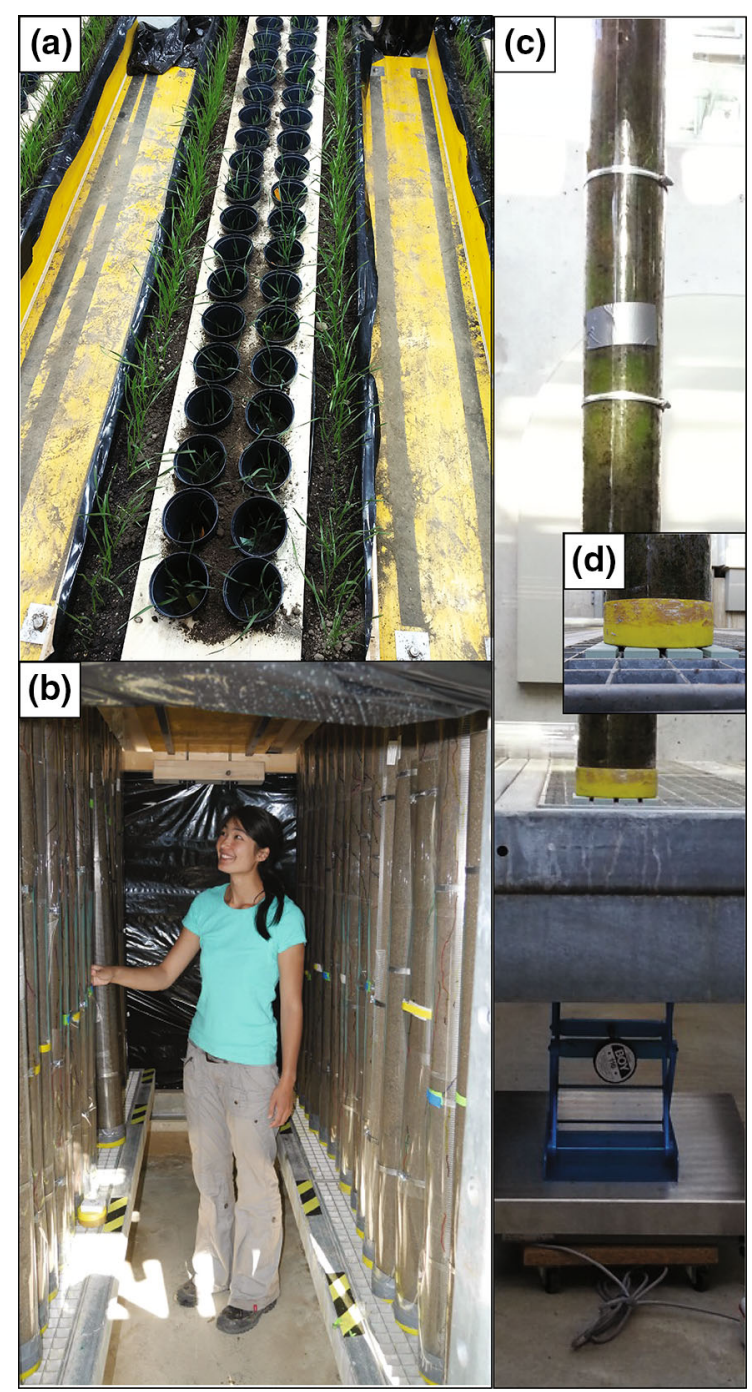

Fig. 1 The deep root observation platform (DROP) separated in an upper part to evaluate shoot growth (a) and a lower part to observe root growth and weigh the columns (b). Each column (c) is divided in two halves, fixed by metal clamps and tape. The bottom of the column is closed with a protection cap containing holes for drainage. A rising platform based on a scale is used to lift up the columns to determine their weight (d)
$11 \mathrm{~cm}$ in width). Each column was divided longitudinally in two halves, to ease the root harvest, and held together with clamps and tape (Fig. 1c). The bottom of each column was covered by a protection cap with holes to drain excess water (Fig. 1d). A double row of columns was arranged under a board with holes through which the wheat plants grew (Fig. 1a). There was a gap between the upper part of the columns and the board to enable lifting them up for weighing. To hold the columns in place and shield the root area from light, a plastic pot $(12 \mathrm{~cm}$ diameter $)$ was inserted through the holes in the board and into the growth column (Fig. 1a). In total, eight rows of 16 columns each $(n=144)$ were arranged on a metal grid. The below-ground part of the platform was shaded from all sides by black foil to shield the root systems from direct light.

In order to follow the water balance in the columns of the water-stress treatment, a scale (Soehnle Type 9056.03.001, Nassau, Germany) was placed on a rolling car (Fig. 1c, d). The scale could be positioned below individual columns and lifted manually by means of a lab jack to take the column weight. The procedure was repeated every three to four days for the 56 columns of the early water stress treatment. As weighing took more than $4 \mathrm{~h}$, the control columns were not weighted but regularly watered as described in water treatments.

\section{Plant material}

We selected a set of 14 Swiss bread wheat varieties representing the top selling wheat varieties in their era (Swiss "era" wheats) covering the last 100 years of Swiss bread wheat breeding (Fossati and Brabant 2003) as well as promising future varieties $(\mathrm{CH}$ Combin, Suretta and Simano) which had reached wide acceptance by farmers (Fig. 2). The set comprised four old varieties released between 1910 and 1960 (Fig. 2). Zenith was the first Swiss genotype containing such semi-dwarf genes (Fig. 2). Arina was cultivated for the longest period of time and $\mathrm{CH}$ Claro is the most successful recent variety in the set. Seeds were obtained from the Swiss gene bank (Agroscope, Changins, Switzerland) and from Delley seeds and plants Ltd (Delley Castle, Delley, Switzerland). The material was multiplied in the field season 2012/2013 at the ETH research station Lindau-Eschikon. 

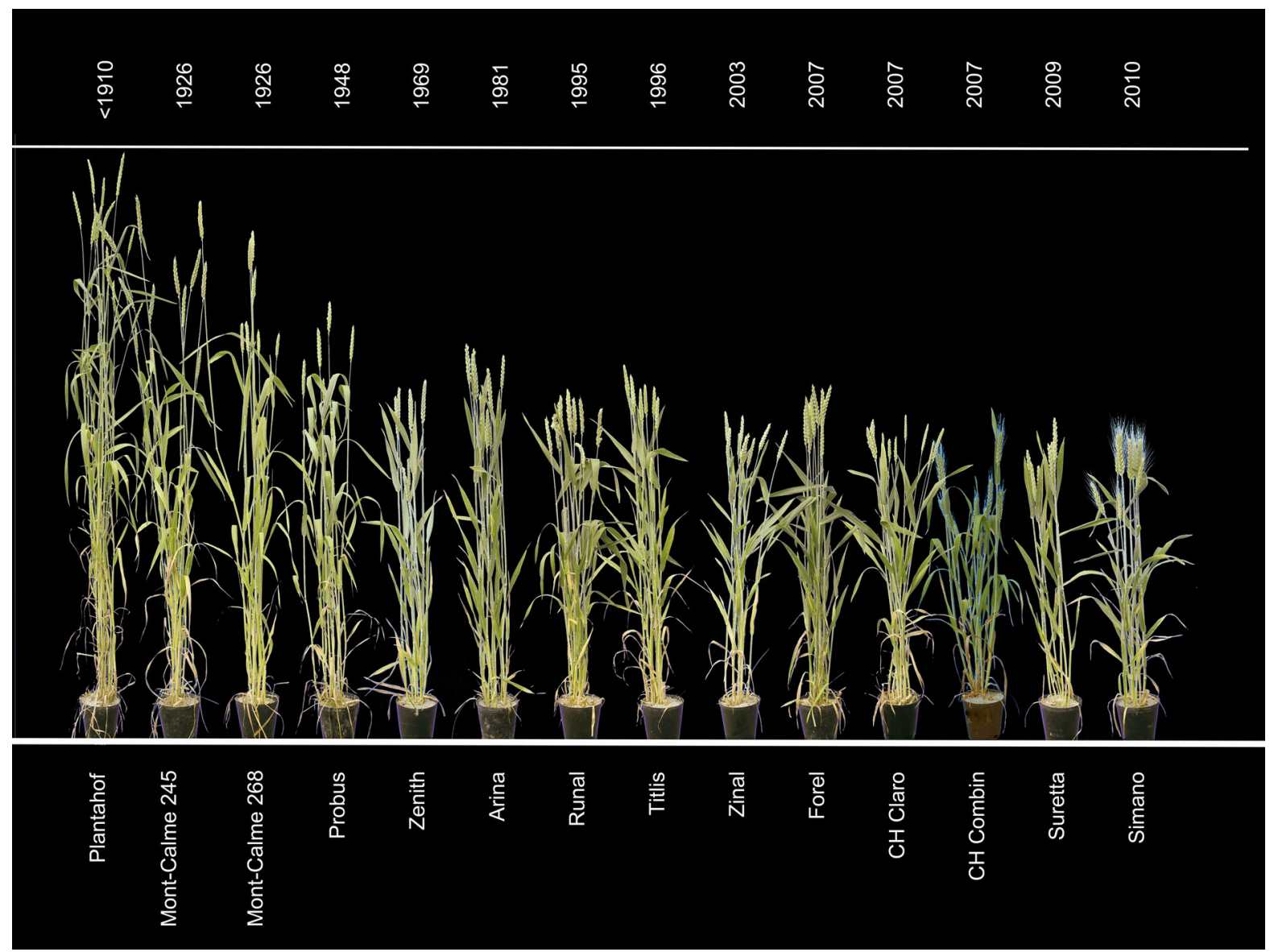

Fig. 2 The Swiss "era" wheat varieties (all varieties released before 2007 including $\mathrm{CH}$ Claro) and three promising new varieties covering $\sim 100$ years of Swiss bread wheat breeding. Zenith was the first variety in the breeding program containing

Growth conditions

The experiment was conducted between December 2013 and July 2014. The fourteen bread wheat genotypes were sampled at two dates (flowering and maturity) and at three water availability treatments, i.e. well-watered (WW) control, early water stress (EWS) and late water stress (LWS). Each of the two sampling dates was a full factorial design with two complete replications. At flowering (BBCH stage 65; Lancashire et al. 1991) two treatments (WW and EWS) were harvested while at maturity (BBCH 90) three treatments (WW, LWS and a recovered EWS) were harvested. This resulted in a total of 56 and 84 experimental units for the harvest at flowering and semi-dwarf genes. The imaged plants were excavated from $1.5 \times 2 \mathrm{~m}$ plots in the field of ETH research station EschikonLindau in 2014 and put into pots for imaging

maturity, respectively. The experimental unit was one column with three plants of the same variety.

The 162 acrylic plastic columns (140 for the treatments and 22 for border plants at the end of the rows) were filled with soil ('Landerde', RICOTER Erdaufbereitung AG, Aarberg, Switzerland) consisting of $25 \%$ clay, $35 \%$ silt and $40 \%$ sand. To reduce the nutrient content of the top- $(0-25 \mathrm{~cm})$ and subsoil $(>25 \mathrm{~cm})$, the RICOTER Landerde substrate was mixed with quartz sand of $0.08-0.2 \mathrm{~mm}$ grain size (10\% and $30 \%$ sand in top and subsoil, respectively). Soil organic matter was $7 \%$ and the $\mathrm{pH}$ was 7.24 . The RICOTER substrate contained $223.2 \mathrm{~g} / \mathrm{m}^{3}$ total nitrogen, $101.0 \mathrm{~g} / \mathrm{m}^{3}$ phosphor, $571.1 \mathrm{~g} / \mathrm{m}^{3}$ potassium, $51.1 \mathrm{~g} / \mathrm{m}^{3}$ magnesium and $613.3 \mathrm{~g} / \mathrm{m}^{3}$ calcium (RICOTER Erdaufbereitung AG, Aarberg, 
Switzerland). A rubber mallet was used during the column filling to tap on the outer column wallets from the bottom to the top to settle the soil without compacting it. Furthermore, to settle the soil all columns were watered multiple times throughout several days. Soil samples of WW columns were taken to determine the soil bulk density (sampling description in "destructive sampling" paragraph). The average soil bulk density was $0.93 \mathrm{~g} \mathrm{~cm}^{-3}$. The soil bulk density at different depths was as follows: $0.80 \mathrm{~g} \mathrm{~cm}^{-3}(0-25 \mathrm{~cm}), 0.93 \mathrm{~g} \mathrm{~cm}^{-3}(25-50 \mathrm{~cm})$, $0.93 \mathrm{~g} \mathrm{~cm}^{-3}(50-75 \mathrm{~cm}), 1.01 \mathrm{~g} \mathrm{~cm}^{-3}(75-100 \mathrm{~cm})$, $0.99 \mathrm{~g} \mathrm{~cm}^{-3} \quad(100-125 \mathrm{~cm})$ and $0.92 \mathrm{~g} \mathrm{~cm}^{-3}$ $(125-150 \mathrm{~cm})$. Seeds were germinated in a watered tray with fleece and anti-algae foil (Aquaplus AntiAlgenfolie) for 3-4 days. Seedlings (three plants per tube) with emerged coleoptiles were planted at day 0 in PVC tubes (20 cm in length, $7 \mathrm{~cm}$ in width) placed in a growth chamber (Conviron, Winnipeg, Canada) for vernalization. Plants were grown at $4^{\circ} \mathrm{C}, 60 \%$ relative humidity and a $8 \mathrm{~h}$ photoperiod at $135 \mu$ mol m${ }^{-2} \mathrm{~s}^{-1}$ light intensity at canopy level for 58 days. To avoid devernalization, temperatures were gradually increased to $16{ }^{\circ} \mathrm{C} / 12{ }^{\circ} \mathrm{C}$ (day/night) at 486 $\mu \mathrm{mol} \mathrm{m}{ }^{-2} \mathrm{~s}^{-1}$ light intensity during the day. After vernalization (59 days after sowing), plants were transplanted from the small PVC tubes to the acrylic growth columns in the DROP greenhouse. Environmental conditions were as follows: Temperature at $20{ }^{\circ} \mathrm{C} / 18{ }^{\circ} \mathrm{C}$ (day/night), $60 \%$ relative humidity and a minimum of $12 \mathrm{~h}$ of light was provided by metal halide lamps (EYE-lighting international). Three plants per column ensured a planting density of 375 plants $/ \mathrm{m}^{2}$ soil surface in the columns, which matches the typical planting density in the field. The distance between the columns within the rows was $3.0 \mathrm{~cm}$; the distance between two rows of columns and border plants was $12.5 \mathrm{~cm}$.

\section{Water treatments}

The soil moisture in all columns was first adjusted to field capacity $35.25 \%$ for topsoil and $35.64 \%$ for subsoil gravimetric water content). For early water stress water was withheld between 61 days after sowing (DAS) until flowering and re-watered until maturity. The effect of early water stress level was monitored by measuring the development of plant height. To avoid too severe stress, EWS plants were watered, if their average reduction in plant height exceeded more than $20 \%$ of the control plants $(50 \mathrm{ml}$ at $90 \mathrm{DAS}$ and $100 \mathrm{DAS}, 100 \mathrm{ml}$ at $126 \mathrm{DAS}$ ). For late water stress, water was withheld from 2 weeks before flowering until maturity. Weights of the EWS columns were taken two times per week to observe the water loss by evapotranspiration. The control treatment was kept at field capacity by watering the columns two to three 3 times per week until water was dripping out at the bottom of the columns.

\section{Shoot parameters}

Plant height was measured two to three times a week by determining the highest point of the tallest plant per column. Important growing stages of flowering and maturity were monitored and classified according to BBCH (Lancashire et al. 1991). At harvest, Straw was harvested, ears and flag leaves were separated and dry matter of ears $\left(\mathrm{DW}_{\mathrm{Ear}}\right)$ and straw $\left(\mathrm{DW}_{\mathrm{St}}\right)$ was determined after oven drying at $65{ }^{\circ} \mathrm{C}$ for $48 \mathrm{~h}$. The rootshoot ratio was determined by taking the total shoot biomass including stems and leaves without ears.

\section{Root parameters}

For root harvest, the columns were opened, divided in six segments of $25 \mathrm{~cm}$ and total rooting depth was measured. Roots of each segment were washed, dried at $65{ }^{\circ} \mathrm{C}, 48 \mathrm{~h}$ and weighed to determine root dry weight $\left(\mathrm{DW}_{\mathrm{Rt}}\right)$. The depth reached by $95 \%$ of the roots $\left(D_{95}\right)$ was determined according to Grieder et al. (2014) who adopted the method described by Schenk and Jackson (2002).

Soil samples of ten EWS, LWS and WW columns were taken to measure soil moisture content at each harvest time by taking a soil bulk density probe (cylinder of $25 \mathrm{~mm}$ diameter and $100 \mathrm{~mm}$ length). The soil samples of the WW treatment were used to determine the bulk density of the columns.

\section{Statistics}

To evaluate the effect of breeding progress, the dependency of different traits on the year of release was evaluated in a mixed linear model using the $\mathrm{R}$ package ASReml (Butler 2006). The aim of the analysis was to determine whether the measured traits showed a linear dependency on the year of release of 
the varieties and if this dependency was further affected by the water treatment and harvest time. The following complete model was:

$$
\begin{aligned}
y_{i j k l m}= & t_{i}+h_{j}+a_{k}+b_{i} a_{k}+c_{j} a_{k}+h_{i j}+d_{i j} a_{k}+h_{j l} \\
& +e_{j l} a_{k}+e_{i j k l m}
\end{aligned}
$$

where $y_{\mathrm{ijklm}}$ is the trait value of the ith treatment ( $i=\mathrm{WW}$ or EWS), in the $\mathrm{jth}$ harvest time $(\mathrm{j}=$ flowering or maturity) the kth year of release $(\mathrm{m}=$ year as numeric variable), the lth replication $(1=1$ or 2$)$ and the mth genotype released within a year. The fixed main effect were treatment $(t)$, harvest time (h), and year of release (a). The fixed interaction terms were year-by-treatment $\left(b_{i} a_{k}\right)$, year-by-harvest time $\left(c_{j} a_{k}\right)$, treatment-by-harvest time $\left(\mathrm{th}_{\mathrm{ij}}\right)$ and year-by-treatment-by-harvest time $\left(\mathrm{d}_{\mathrm{ij}} \mathrm{a}_{\mathrm{k}}\right)$. As year was a covariate, the estimates of the year effect itself and all interactions with the year effect, represent development rates (slopes) of trait changes in dependence of the year of release. The random terms were replication within harvest time $\mathrm{hr}_{\mathrm{jl}}$ (intercept) and the random deviation of the slopes $\mathrm{e}_{\mathrm{j} 1}$ of each replication within harvest time regressed over year of release $a_{k}$. To evaluate the effect within harvest time and test also the LWS effect the model was simplified by dropping the terms containing the factor harvest time $\left(\mathrm{h}_{\mathrm{j}}\right)$ and the slope effect $\left(c_{j}\right)$.

To evaluate differences among genotypes the following mixed linear model was adjusted:

$$
\begin{aligned}
\mathrm{y}_{\mathrm{ijklm}}= & \mathrm{t}_{\mathrm{i}}+\mathrm{h}_{\mathrm{j}}+\mathrm{g}_{\mathrm{m}}+\mathrm{th}_{\mathrm{ij}}+\mathrm{tg}_{\mathrm{im}}+\mathrm{gh}_{\mathrm{jm}}+\mathrm{thg}_{\mathrm{ijm}} \\
& +\mathrm{hr}_{\mathrm{jl}}+\mathrm{e}_{\mathrm{ijlm}}
\end{aligned}
$$

where $g_{m}$ is the effect of the mth genotypes and its interactions with the treatment $\left(\operatorname{tg}_{\mathrm{im}}\right)$, harvest time $\left(\mathrm{gh}_{\mathrm{jm}}\right)$ and both, treatment and harvest time $\left(\mathrm{thg}_{\mathrm{ijm}}\right)$. The other parameters were the same as for model 1. Best linear unbiased estimates for the genotypic effects were calculated within the EWS and WW, respectively. The values were averaged across the two harvest times to obtain 4 replications per genotype and treatment. The averaging was justified as many traits did not show a significant genotype-harvest interaction (Tab. S1). A Tukey HSD test calculated based on the average standard error of the difference between genotypes to adjust for multiple testing.

\section{Results}

Water-stressed plants reduced their elongation rates early in development and became shorter

Plants at early water stress showed a steady water uptake indicated by the average decrease of column weight by $0.014 \mathrm{~kg}$ per day until flowering (Fig. 3a). The height of EWS plants started to lag behind the WW plants for 80 DAS (19 days without watering) onwards (Fig. 3b). Plants exposed to EWS reached their final height around 30 days earlier compared to WW and stayed around 20\% shorter (Fig. 3b). The LWS treatment had no pronounced effect on the final height, as water was supplied until 14 days before flowering stage was reached.

There was a more or less uniform distribution of water at the time of harvest (Fig. 4). Strong differences were observed for EWS only, which showed considerably higher water content in the topsoil $(<25 \mathrm{~cm})$ at flowering. The subsoil gravimetric water content of the EWS at flowering was on average $18 \%$ compared to $25 \%$ of the well-watered control (Fig. 4a). At maturity, the difference to the drought treatment was even more pronounced with $8 \%$ for late water stress compared to $21 \%$ for WW (Fig. 4b). At final harvest, the soil moisture content of EWS columns was higher compared to WW columns for all depths although both treatments were watered equally The increased soil moisture content in EWS columns at maturity could be caused by the lowered plant biomass as a result of the previous water stress.

Modern varieties showed decreased rooting depth without stress but increased ability to root deep under drought

The analysis of covariance revealed a highly significant $(p<0.001)$ effect of year of release and year of release-by-treatment interaction for the traits $D_{95}$, $\mathrm{DW}_{\mathrm{Rt}}, \mathrm{Ht}_{\mathrm{Plt}}$ and $\mathrm{DW}_{\mathrm{St}}$ (Table 1). While the significant year effect indicates a clear overall breeding trend (slope) for these traits, the significant interaction indicates that the trends differed for water stress and well-watered conditions. The treatment affected the traits $\mathrm{DW}_{\mathrm{Rt}}$ and the root biomass for all column segments $(0-150 \mathrm{~cm}$ divided in $25 \mathrm{~cm}$ parts).

Under WW conditions, there was a negative trend between $D_{95}$ and the year of release $\left(0.5 \mathrm{~cm} \mathrm{a}^{-1}\right.$ at 
Fig. 3 Development of the average column weight (a) and the average plant height (b) until flowering for the following treatments: well-watered (blue circles), early water stressed (red triangle) and late water stressed (purple diamonds). (Color figure online)
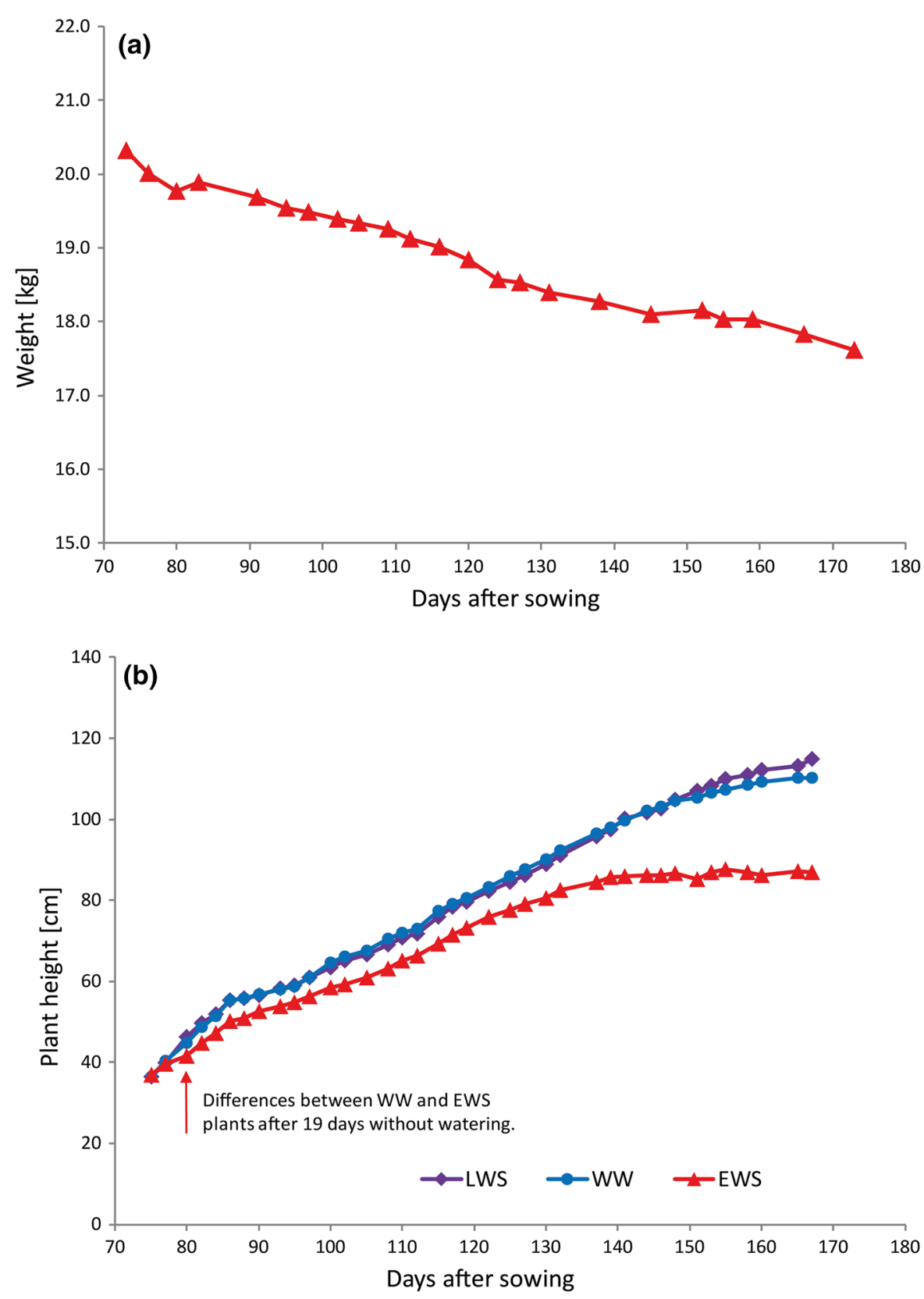

flowering and $0.71 \mathrm{~cm} \mathrm{a}^{-1}$ at maturity) (Fig. 5). When the varieties were exposed to EWS, this negative trend disappeared: older varieties tended to respond with decreased $D_{95}$, while modern varieties increased $D_{95}$ (Fig. 5a). We tested if the response, i.e. the slopes of the regression of $D_{95}$ versus year of release for WW and EWS, differed. The slopes differed significantly ( $p<0.001)$, indicating that there was breeding progress for responsiveness to drying soil. Similarly, under LWS, modern varieties could further increase their rooting depth after flowering while old varieties did not show this potential (Fig. 5b). However, the slopes for WW and LWS differed at the $15 \%$ significance level, only. Thus, the number of two replications was not high enough to statistically prove this effect.

The utility of $\mathrm{D}_{95}$ to differentiate the varieties with regard to their rooting depth is supported by the 


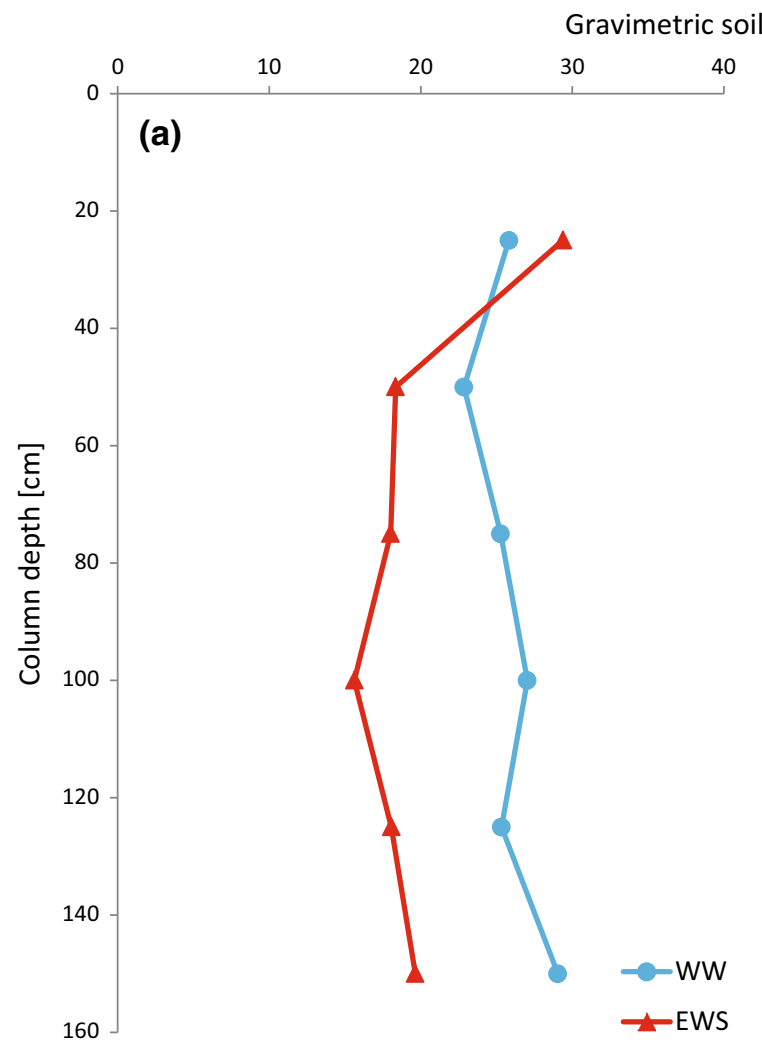

Fig. 4 Water distribution within the columns of different water treatments at flowering (a) and at maturity (b) for the treatments well-watered (blue circles) early water stressed (red triangles)

Table 1 Analysis of covariance between year of release (year), water treatment (treat), harvest time (harvest), year of release-by-harvest interaction and treatment-by-harvest interaction and rooting depth $\left(D_{95}\right)$, total root dry weight $\left(D_{\mathrm{Rt}}\right)$, dry weight of straw $\left(\mathrm{DW}_{\mathrm{St}}\right)$, ear dry weight $\left(\mathrm{DW}_{\mathrm{Ear}}\right)$ and final plant height $\left(\mathrm{Ht}_{\mathrm{Plt}}\right)$ at flowering and at maturity

\begin{tabular}{llllll}
\hline Factor & $\mathrm{D}_{95}$ & $\mathrm{DW}_{\mathrm{Rt}}$ & $\mathrm{DW}_{\mathrm{St}}$ & $\mathrm{DW}_{\text {Ear }}$ & $\mathrm{Ht}_{\mathrm{Plt}}$ \\
\hline (Intercept) & $* * *$ & $* * *$ & $* * *$ & $* * *$ & \\
Year & $* * *$ & $* * *$ & $* * *$ & $* *$ & $* * *$ \\
Treat & 0.14 & $* * *$ & $* * *$ & $* * *$ & $* * *$ \\
Harvest & $* * *$ & 0.7 & 0.4 & $* * *$ & $* * *$ \\
Year:treat & $* * *$ & $* * *$ & $* * *$ & 0.14 & $*$ \\
Year:harvest & 0.2 & 0.05 & $*$ & 0.13 & $* * *$ \\
Treat:harvest & $*$ & 0.36 & 0.71 & $* * *$ & 0.66
\end{tabular}

Data are based on 14 genotypes studied over two replications for each water treatment and harvest time

The probabilities $(* p \leq 0.05 ; * * p \leq 0.01$, ***p $\leq 0.001)$ are shown. For non-significant effects, the respective $p$ values are shown

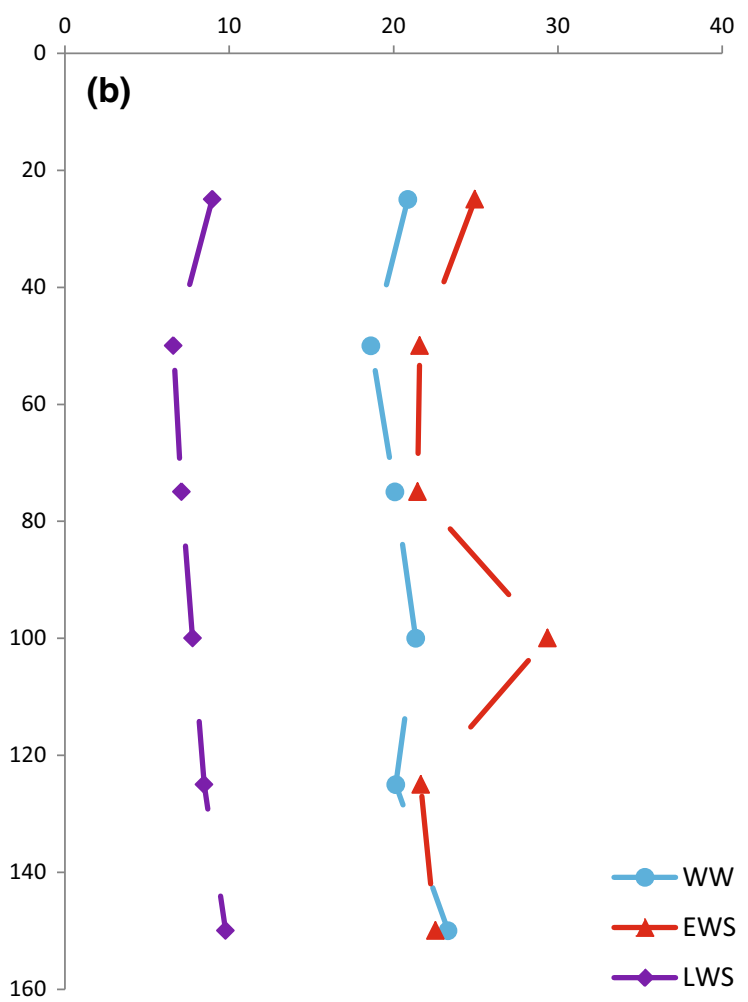

and late water stressed (purple diamonds). Each symbol represents the average of ten samples $(25 \mathrm{~mm}$ width, $100 \mathrm{~mm}$ width) of randomly chosen growth columns per treatment. (Color figure online)

absolute root weights in the lowest column sections. The Pearson correlation between $\mathrm{DW}_{\mathrm{Rt}}$ between 125 and $150 \mathrm{~cm}$ and $D_{95}$ was reasonably strong $(0.85$ for WW and 0.76 for EWS; Tab. S2). Furthermore, under WW conditions the most recent three genotypes, frequently allocated less biomass to column sections below $75 \mathrm{~cm}$, compared to the pre-green revolution varieties (Tab S3). Under EWS conditions root biomass did not differ for any genotype at any column section (Tab S3).

Rooting depth was related to plant height for WW but not for EWS conditions

As breeders selected for decreased height, it seems likely, that rooting depth decreases as well. This assumption of a simple allometric relationship is corroborated by the positive correlation between plant height and $\mathrm{D}_{95}$ under WW conditions at flowering 


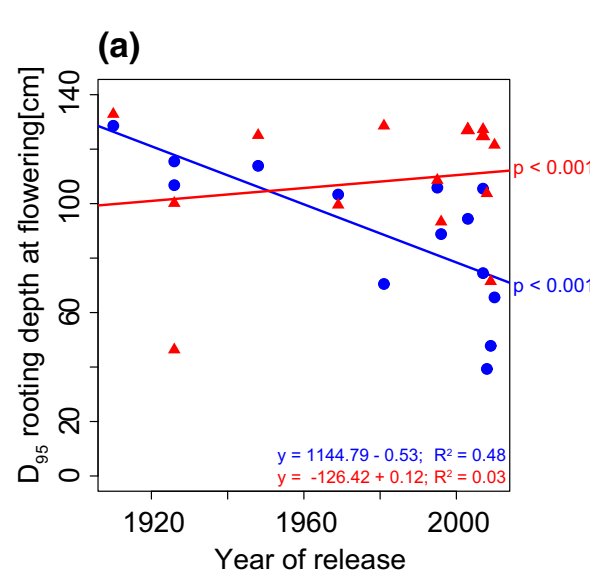

Fig. 5 The depth reached by $95 \%$ of the root biomass $\left(D_{95}\right)$ in the deep root observation platform as a function of the year of release of 14 historic and modern Swiss wheat varieties. Roots were sampled at flowering (a) and at maturity (b) for wellwatered (blue circles), early water stressed (red triangles) and late water stressed (purple diamonds) treatment. The straight

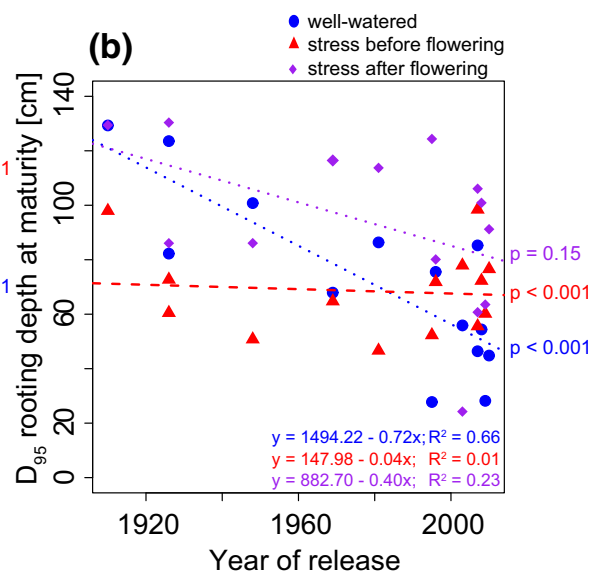

lines indicate the responses to year of release calculate in model 1. $p$ values indicate the difference of the slopes of the stress treatments compared to the slopes of the well-watered control. Each symbol represents the average of two replications. (Color figure online)
Fig. 6 Relationship between rooting depth $\left(D_{95}\right)$ and plant height at both flowering (a) and maturity (b) and relationship between root dry weight $\left(\mathrm{DW}_{\mathrm{Rt}}\right)$ and shoot dry weight $\left(\mathrm{DW}_{\mathrm{St}}\right)$ at flowering (c) and at maturity (d) for well-watered (blue circles), early water stressed (red triangles) and late water stressed (purple diamonds) treatment. (Color figure online)
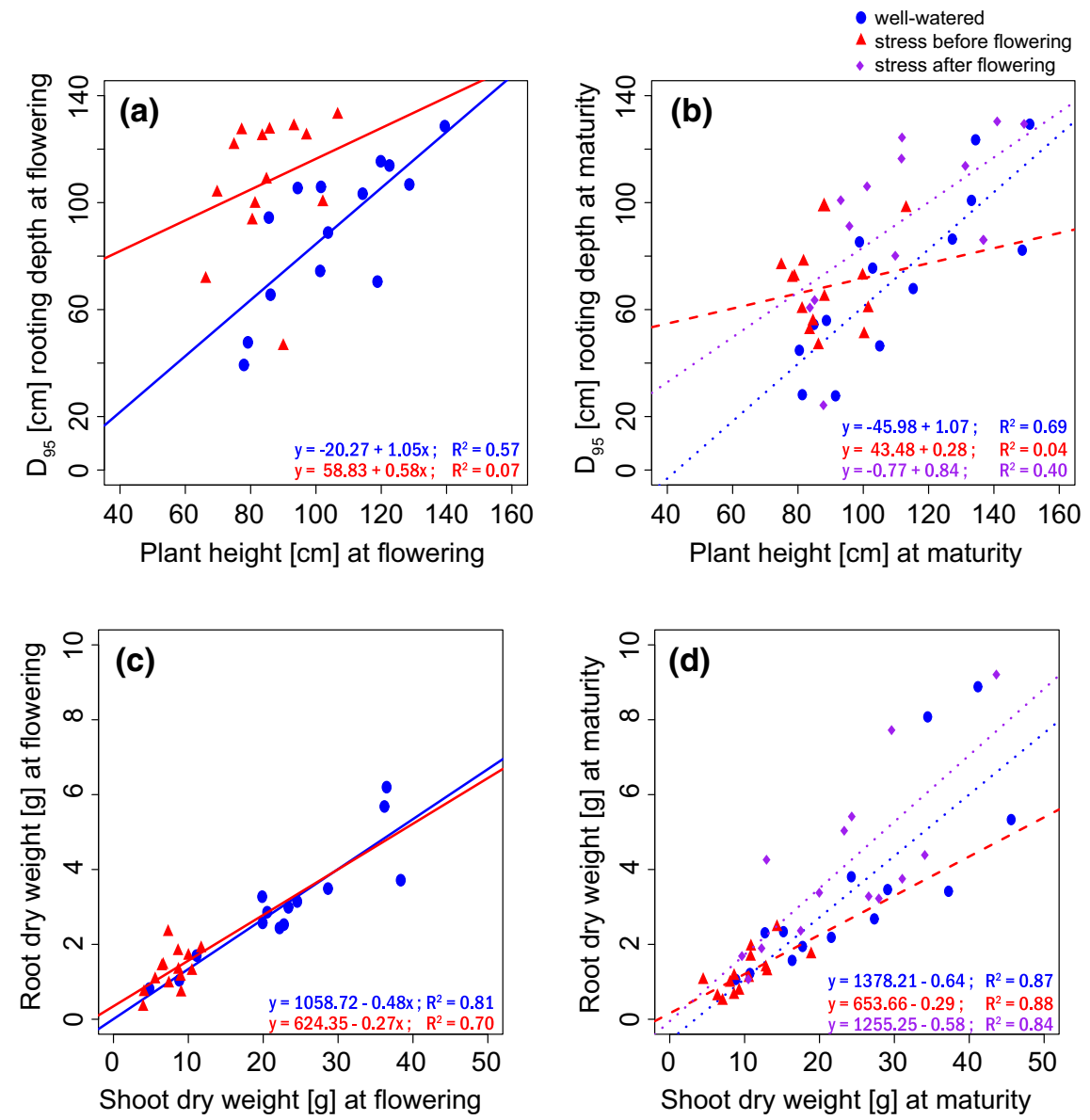
$\left(\mathrm{R}^{2}=0.57\right)$ and maturity $\left(\mathrm{R}^{2}=0.69\right)($ Fig. 6a, b). At both harvest dates, similar relationships between plant height and depth were found: per centimeter increase in height, rooting depth increased by $1.05-1.07 \mathrm{~cm}$ for flowering and maturity, respectively. However, $\mathrm{D}_{95}$ was about $25 \mathrm{~cm}$ lower at maturity, indicating a relative change in root distribution. However, the relationship disappears, when plants were exposed to early water stress: rooting depth could not be predicted anymore from plant height $\left(\mathrm{R}^{2}=0.07\right.$ and 0.04 for flowering and maturity, respectively). Final plant height of EWS plants was reduced by $20 \%$. The LWS treatment (maturity $\mathrm{R}^{2}=0.40$ ) showed a trend for increased rooting depth and increased plant height at maturity compared to well-watered treatment plants. Average values of above and below ground plant traits ordered by genotype and treatment are shown in the supplementary material (Tab. S3).

There was also a strong relationship between root and shoot dry weight under WW conditions at flowering $\mathrm{R}^{2}=0.81 \quad$ (Fig. 6c) and at maturity $\mathrm{R}^{2}=0.64$ (Fig. 6d). We observed a $67 \%$ reduction in above ground biomass and a reduction of $59 \%$ in root biomass under EWS compared to WW at flowering. For the root-shoot ratio, we observed only significant water treatment effects but no genotype effects or interactions. The EWS treatment reduced the vegetative stem and leaf biomass to a larger degree $(-66 \%, p<0.001)$ than it affected the root biomass $(-57 \%, p<0.001)$. This led to a $26 \%$ increase in the root-shoot ratio from 0.12 to $0.16(p<0.05)$. The LWS treatment resulted in a relative decrease of above ground biomass $(-20 \%)$ as a result of $60 \%$ $(p<0.001)$ lower ear weights due to a reduced grain filling. This resulted in a 20\% $(p<0.05)$ higher rootshoot ratio under LWS $(0.16)$ treatment compared to WW (0.1).

For all treatments, the majority of the roots were in the topsoil

Water limitation at different time periods affected the vertical distribution of root dry weight density (Fig. 7). Root biomass decreased by more than $90 \%$ from the first $0-25 \mathrm{~cm}$ segment to the following $25-50 \mathrm{~cm}$ segment for all water treatments at both harvest times, respectively. The EWS treatment resulted in a decrease in the root weight density in the top $100 \mathrm{~cm}$ (flowering; Fig. 7a) or even

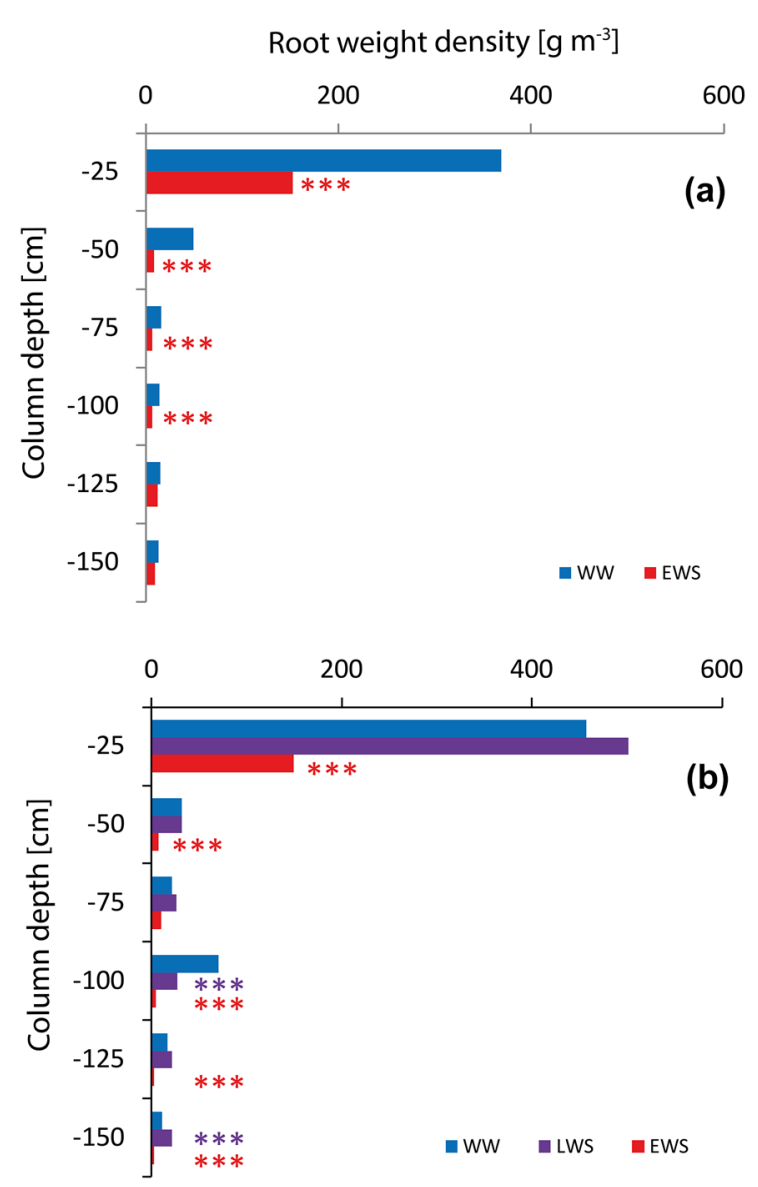

Fig. 7 Average root weight density distribution in different column depths for EWS and WW treatment at flowering (a) and for EWS, LWS and WW treatment at maturity (b). The root weight density is given on a per-plant i.e. is $1 / 3 \mathrm{rd}$ of the total density

throughout the whole profile (maturity; Fig. 7b) with the exception of the $50-75 \mathrm{~cm}$ segment. The LWS treatment resulted a relatively greater root weight density in the segment below $125 \mathrm{~cm}$ (Fig. 7b).

Modern varieties showed considerable variation in rooting depth despite similar plant height

Apart from the general trend related to the year of release, there was substantial genetic variability with respect to rooting depth, particularly among the modern varieties released after 2007 (Forel to Simano). Under WW conditions, rooting depth $\mathrm{D}_{95}$ varied from $38 \mathrm{~cm}$ (Suretta) to $95 \mathrm{~cm}$ (CH Claro) among the modern varieties, whereas the height was fixed between $80 \mathrm{~cm}$ and $100 \mathrm{~cm}$ (Table 2). Under 
Table 2 Best linear unbiased estimators (BLUEs) for rooting depth $\left(\mathrm{D}_{95}\right)$, root dry weight $\left(\mathrm{DW}_{\mathrm{Rt}}\right)$ and final plant height $\left(\mathrm{Ht} \mathrm{Plt}_{\mathrm{Pl}}\right)$ of the different genotypes at flowering, well-watered and early water stress conditions

\begin{tabular}{|c|c|c|c|c|c|c|c|}
\hline \multirow[t]{2}{*}{ Year of release } & \multirow[t]{2}{*}{ Genotype } & \multicolumn{3}{|l|}{ Well-watered } & \multicolumn{3}{|c|}{ Early water stressed } \\
\hline & & $\mathrm{D}_{95}(\mathrm{~cm})$ & $\mathrm{DW}_{\mathrm{Rt}}(\mathrm{g})$ & $\mathrm{Ht}_{\text {Plt }}(\mathrm{cm})$ & $\mathrm{D}_{95}(\mathrm{~cm})$ & $\mathrm{DW}_{\mathrm{Rt}}(\mathrm{g})$ & $\mathrm{Ht}_{\mathrm{Plt}}(\mathrm{cm})$ \\
\hline 1910 & Plantahof & $129.0 \mathrm{a}$ & $1.50 \mathrm{abc}$ & $145.2 \mathrm{a}$ & $115.4 \mathrm{a}$ & $0.60 \mathrm{a}$ & $109.9 \mathrm{a}$ \\
\hline 1926 & MC 245 & $119.5 \mathrm{ab}$ & $1.53 \mathrm{abc}$ & $127.1 \mathrm{bc}$ & $59.5 \mathrm{a}$ & $0.47 \mathrm{a}$ & $94.9 \mathrm{bcd}$ \\
\hline 1926 & MC 268 & $94.5 \mathrm{abcd}$ & $2.07 \mathrm{ab}$ & $138.6 \mathrm{ab}$ & 80.3 a & $0.63 \mathrm{a}$ & $101.8 \mathrm{ab}$ \\
\hline 1948 & Probus & $107.3 \mathrm{abc}$ & $2.37 \mathrm{a}$ & $127.8 \mathrm{bc}$ & 87.9 a & $0.47 \mathrm{a}$ & $98.7 \mathrm{abc}$ \\
\hline 1969 & Zenith & 85.6 abcde & $1.07 \mathrm{bcd}$ & $114.8 \mathrm{~cd}$ & $82.1 \mathrm{a}$ & $0.33 \mathrm{a}$ & 84.7 def \\
\hline 1981 & Arina & 78.4 abcde & $1.10 \mathrm{bcd}$ & $123.1 \mathrm{bc}$ & $87.6 \mathrm{a}$ & $0.47 \mathrm{a}$ & 89.8 bcde \\
\hline 1995 & Runal & 66.8 bcde & $0.83 \mathrm{~cd}$ & $96.5 \mathrm{ef}$ & $80.5 \mathrm{a}$ & $0.37 \mathrm{a}$ & 84.2 def \\
\hline 1996 & Titlis & 82.2 abcde & $0.87 \mathrm{~cd}$ & $103.3 \mathrm{de}$ & $82.6 \mathrm{a}$ & $0.50 \mathrm{a}$ & 79.4 ef \\
\hline 2003 & Zinal & 75.2 abcde & $0.33 \mathrm{~cd}$ & 87.0 ef & $102.5 \mathrm{a}$ & $0.27 \mathrm{a}$ & $79.5 \mathrm{ef}$ \\
\hline 2007 & Forel & $60.4 \mathrm{cde}$ & $0.93 \mathrm{bcd}$ & $103.2 \mathrm{de}$ & $112.9 \mathrm{a}$ & $0.33 \mathrm{a}$ & $86.9 \mathrm{cdef}$ \\
\hline 2007 & $\mathrm{CH}$ Claro & 95.4 abcd & $0.77 \mathrm{~cd}$ & $96.6 \mathrm{ef}$ & 90.2 a & $0.20 \mathrm{a}$ & $84.1 \mathrm{def}$ \\
\hline 2007 & $\mathrm{CH}$ Combin & $46.9 \mathrm{de}$ & $0.30 \mathrm{~d}$ & $81.4 \mathrm{f}$ & 88.0 a & $0.23 \mathrm{a}$ & $74.3 \mathrm{f}$ \\
\hline 2009 & Suretta & $38.0 \mathrm{e}$ & $0.67 \mathrm{~cd}$ & $80.2 \mathrm{f}$ & $65.8 \mathrm{a}$ & $0.50 \mathrm{a}$ & $73.8 \mathrm{f}$ \\
\hline 2011 & Simano & $55.2 \mathrm{cde}$ & $0.73 \mathrm{~cd}$ & $83.3 \mathrm{f}$ & $99.1 \mathrm{a}$ & $0.50 \mathrm{a}$ & $74.9 \mathrm{f}$ \\
\hline
\end{tabular}

Genotypes are ordered by year of release. Means followed by the same letters are not significantly different $(p \leq 0.05)$ according to Tukey's HSD (honest significant difference) test. For further traits see supplemental Table S3

MC Mont-Calme

these conditions, the modern variety $\mathrm{CH}$ Claro rooted almost as deep as the old varieties and rooted significantly deeper than the genotype Suretta although both genotypes differ little in final plant height (Tab. S3). Under early water stress, there was no significant difference among individual varieties for rooting depth or root dry weight (Tables 2, S3) but still significant differences in height between old and modern varieties.

\section{Discussion}

A platform to evaluate rooting depth of wheat under conditions close to the field

Plants in the DROP platform grew in tall columns at a common field plant density of 375 plants per $\mathrm{m}^{2}$ to simulate realistic conditions. To avoid negative effects of small pot sizes, such as restricted root zones leading to water and nutrient limitations, a column depth of $160 \mathrm{~cm}$ was chosen. It is known that plant density and pot size affect plant growth and root-shoot ratios (Krizek et al. 1985; Hussain et al. 2016; Poorter et al.
2012). Poorter et al. (2012) highlighted that root mass increases with smaller pot size, but decreases shoot biomass due to limited nutrient and water availability. Several studies observed rooting depths of wheat between 80 and $180 \mathrm{~cm}$ under field conditions in Australia (Tennant 1976; Incerti and Oleary 1990; Kirkegaard and Lilley 2007) and between 50 and $195 \mathrm{~cm}$ in tube rhizotrons (Ytting et al. 2014). The soil moisture content at both harvest times was more or less uniformly distributed over column depth, also in the EWS treatment which was not extensively dewatered (Fig. 4). Hund et al. (2009) reported a much steeper gradient in $80 \mathrm{~cm}$ columns which were not watered during the experiment and showed that shallow rooting maize genotypes could not take up water from the lower part of the soil columns. However, the study used a sand mixture with much lower water holding capacity, which led to a stronger vertical gradient with more water at the bottom of the column. The substrate used in the present experiment is closer to field conditions. However, we assume that rooting depth in the DROP is still overestimated due to (1) higher soil temperatures, (2) a lower soil bulk density and (3) border effects between the soil and the 
surface of the column wall. The depth penetration rate of roots in tube rhizotrons was reported to be twice as high as those observed in the field (Ytting et al. 2014). Thus, tubes rather tend to overestimate the differences among genotypes. It remains to be evaluated, if the ranking among genotypes in column experiments is representative for the ranking under field conditions.

Negative relation between year of release and rooting depth under well-watered conditions

Semi dwarf varieties derived by the introgression of reduced height $(R h t)$ genes were major drivers of the green revolution. There were two phases of height adaptation: the green revolution in which height was reduced to about $1 \mathrm{~m}$ by introgression of semi-dwarf Rht genes and a second phase in which height was further reduced without introgression of single genes of major effect. Zenith released in 1969 was the first semi-dwarf variety in the Swiss breeding program with an average final plant height of $100-110 \mathrm{~cm}$. Its $R h t$ gene was introgressed from the Canadian line C 3842-3663. The variety Arina released in 1981 serves as upper height standard for the current Swiss breeding program.

Our results showed deeper rooting of old genotypes compared to modern varieties under WW conditions (Fig. 5). Thus, rooting depth concomitantly decreased with decreasing plant height. Little is known about the diversity of $R h t$ genes within the Swiss varieties. Yet, $R h t$ genes are known to have an effect on rooting behavior. A negative effect of Rht genes was reported for root mass (Elazab et al. 2016) and total root length (Wojciechowski et al. 2009). Other studies did not find a negative effect of semi-dwarfism on root mass or root growth (e.g. Hurd 1974; Lupton et al. 1974; Cholick et al. 1977). The observed different and sometimes opposite effect of the Rht genes on roots may be due to (1) Rht genes and their physiological effect, (2) the genetic background and developmental stage in which the trait was observed and (3) environmental effects, such as soil physical constraints, water and nutrient availability. The importance of genotype-by-environment interaction is demonstrated by the response of the examined genotypes to early water stress as highlighted in the next section.
Modern varieties adapt rooting depth

when exposed to early drought

We found that modern Swiss wheat varieties exposed to early water stress developed less root biomass but reached relatively deeper soil layers, as indicated by $\mathrm{D}_{95}$. Studies in durum wheat and barley confirm the decrease in root dry matter under drought (Barraclough et al. 1989; Zhang et al. 2004; Raziuddin et al. 2010) and the increased rooting depth (Barraclough et al. 1989; Xu et al. 2016; Zhang et al. 2004). Barraclough et al. (1989) observed a deeper rooting of at least $20 \mathrm{~cm}$ under drought for winter wheat, but the total amount of roots in deeper soil layers was small. Severe water shortage impedes root growth (Sharp et al. 1990; Mori et al. 2011) which was certainly the case in the upper part of the soil of the EWS treatment, thus, contributing to a reduced overall root weight.

Modern varieties might respond to late water stress by post-anthesis root growth

During post anthesis, apart from maintenance respiration, the developing grain is assumed to be the only sink organ. Our results indicate that especially for modern varieties, at least some root meristems remain active to forage for soil resources. Post-anthesis root growth in response to availability of water and nutrients in deeper soil layers was also reported for wheat and barley by Manschadi et al. (2006) and for soybean, corn and barley by Dwyer et al. (1988). This indicates that an active root system may be an important component of prolonged grain filling and stay-green under emerging drought towards the end of the growing season. The ability to adjust the root system during grain filling may be especially important for modern varieties, which do not root deep under well-watered conditions during stem elongation.

Rooting depth was linearly related to plant height at WW but not at EWS

Rooting depth indicated by $\mathrm{D}_{95}$ and plant height under well-watered conditions decreased linearly over the last 100 years of breeding (Fig. 5a, b). This relationship cannot be found under EWS conditions. Final plant height was reduced by $20 \%$ under EWS treatment compared to WW treatment (Fig. 3b), whereas synchronously rooting depth for modern varieties 
increased, allowing better access to deeper soil layers (Fig. 5). This is in agreement with results of Carvalho et al. (2014) and Elazab et al. (2016) who reported a stronger reduction of above-ground biomass compared to root biomass and an increased root-shoot ratio under drought. We observed an increase in root-shoot dry weight ratio from 0.14 under WW to 0.22 under EWS. Increased root-shoot ratios under drought conditions were found for cotton (Pace et al. 1999; Malik et al. 1979) and wheat (Carvalho et al. 2014; Elazab et al. 2016). Malik et al. (1979) concluded that the increase in root-shoot ratio under water limited conditions was due to an increase in root biomass, but several authors rather observed a decrease of shoot growth (Carvalho et al. 2014; Elazab et al. 2016; Raziuddin et al. 2010). In our study, the influence of drought on above ground biomass was stronger compared to the influence of drought on below-ground biomass at flowering. For maturity, it was the other way around. Therefore, we conclude that drought increases the root-shoot ratio but that the reason for the increase depends on the time the plant was affected by water limitations.

Modern varieties differed for rooting depth

Modern varieties showed a higher variability in rooting depth than in plant height (Table 1). The modern varieties $\mathrm{CH}$ Claro and Suretta are good examples: $\mathrm{CH}$ Claro was rooting almost as deep as the old, tall varieties while Suretta was rooting very shallow. This is in line with other studies concluding that genetic variability for root biomass was not reduced in modern semi-dwarf genotypes due to breeding (Subira et al. 2016). Rooting depth can be directly related to drought adaptation. Hund et al. (2009) showed that a drought tolerant maize inbred line rooted deeper and took up more water from deeper soil layers compared to an old inbred line with comparably shallow rooting. Deeper rooting of spring wheat SeriM82 was related to improved stay green due to the extraction of deep soil water in Australia (Christopher et al. 2008). With an in-season precipitation of $704.2 \mathrm{~mm}$ at the location of the Swiss breeding nursery, there is certainly limited selection pressure for drought avoidance. However, the program is also conducted under low fertilizer input at $120 \mathrm{~kg} \mathrm{~N} \mathrm{ha}^{-1} \mathrm{a}^{-1}$, which may increase selection pressure for rooting depth. Ytting et al. (2014) observed a faster depth penetration of cultivars bred in Denmark compared to other European countries. They speculated that the strict Danish $\mathrm{N}$ fertilizer regulation might have created a selection pressure for increased nitrogen use efficiency and thereby for deep roots. Comparing the data from Swiss bread with Mediterranean durum wheat (Elazab et al. 2016) indicates that durum has about $66 \%$ of its roots in the subsoil (below $30 \mathrm{~cm}$ ) while Swiss winter wheat had only $20 \%$ of roots in the subsoil (below $25 \mathrm{~cm}$ ). We are not aware of any direct comparison between Mediterranean durum and temperate bread wheat. It is difficult to judge, if these differences may be due to differences between the species, the effect of the selection environment, or the testing system.

\section{Conclusion and outlook}

The data highlights the effect of reduced height and drought on root traits of old and modern Swiss bread wheat genotypes. Reduced plant height of modern varieties coincides with reduced rooting depth under well-watered conditions. Nevertheless, modern varieties responded to drying soil with progressively deeper rooting. The relationship between height and depths decreased under drought stress. It is unlikely that there was an indirect selection for such responsiveness, because in most years there is sufficient precipitation within the target environment. More likely, a general selection for performance of modern varieties led to increased source strength, thereby supplying sufficient carbohydrates to maintain root growth under stress or after anthesis. Rooting depth of modern varieties varied considerably, indicating sufficient variability for selection without changing height. It is not clear, if this variability is a result of the presence of different $R h t$ genes or a result of other morpho-physiological adaptations. Further research may focus (1) on the evaluation of rht genes in the Swiss era wheats and (2) the verification of results under field conditions.

Acknowledgements The authors would like to thank Delley seeds and plants 1td. (Delley Castle, Delley, Switzerland) and Swiss genebank (Agroscope, Changins, Switzerland) for seeds, Hansueli Zellweger, Brigitta Herzog and Patrick Flütsch for technical support, Simon Oberholzer for data collection and Achim Walter for suggestions, comments, reading the Manuscript and financial support. This study was funded by 
the SNF (Project No. 143060) within the framework of the national research programme 68 (www.nrp68.ch).

Open Access This article is distributed under the terms of the Creative Commons Attribution 4.0 International License (http:// creativecommons.org/licenses/by/4.0/), which permits unrestricted use, distribution, and reproduction in any medium, provided you give appropriate credit to the original author(s) and the source, provide a link to the Creative Commons license, and indicate if changes were made.

\section{References}

Aziz MM, Palta JA, Siddique KHM, Sadras VO (2017) Five decades of selection for yield reduced root length density and increased nitrogen uptake per unit root length in Australian wheat varieties. Plant Soil 413(1-2):181-192. https://doi.org/10.1007/s11104-016-3059-y

Barraclough PB, Kuhlmann H, Weir AH (1989) The effects of prolonged drought and nitrogen-fertilizer on root and shoot growth and water-uptake by winter-wheat. J Agron Crop Sci 163(5):352-360. https://doi.org/10.1111/j.1439-037X. 1989.tb00778.x

Brancourt-Hulmel M, Doussinault G, Lecomte C, Berard P, Le Buanec B, Trottet M (2003) Genetic improvement of agronomic traits of winter wheat cultivars released in France from 1946 to 1992. Crop Sci 43(1):37-45

Brisson N, Gate P, Gouache D, Charmet G, Oury FX, Huard F (2010) Why are wheat yields stagnating in Europe? A comprehensive data analysis for France. Field Crop Res 119(1):201-212. https://doi.org/10.1016/j.fcr.2010.07.012

Butler D (2006) asreml: asreml() fits the linear mixed model. R package version 2.00

Carvalho P, Azam-Ali S, Foulkes MJ (2014) Quantifying relationships between rooting traits and water uptake under drought in Mediterranean barley and durum wheat. J Integr Plant Biol 56(5):455-469. https://doi.org/10.1111/jipb. 12109

Chloupek O, Forster BP, Thomas WTB (2006) The effect of semi-dwarf genes on root system size in field-grown barley. Theor Appl Genet 112(5):779-786. https://doi.org/10. 1007/s00122-005-0147-4

Cholick FA, Welsh JR, Cole CV (1977) Rooting patterns of semi-dwarf and tall winter-wheat cultivars under dryland field conditions. Crop Sci 17(4):637-639

Christopher JT, Manschadi AM, Hammer GL, Borrell AK (2008) Developmental and physiological traits associated with high yield and stay-green phenotype in wheat. Aust $\mathbf{J}$ Agric Res 59(4):354-364. https://doi.org/10.1071/ AR07193

Dalrymple DG (1985) The development and adoption of highyielding varieties of wheat and rice in developing-countries. Am J Agric Econ 67(5):1067-1073. https://doi.org/ $10.2307 / 1241374$

Dwyer LM, Stewart DW, Balchin D (1988) Rooting characteristics of corn, soybeans and barley as a function of available water and soil physical characteristics. Can J Soil Sci 68(1):121-132
Elazab A, Serret MD, Araus JL (2016) Interactive effect of water and nitrogen regimes on plant growth, root traits and water status of old and modern durum wheat genotypes. Planta 244(1):125-144. https://doi.org/10.1007/s00425016-2500-z

Fossati D, Brabant C (2003) Selection of wheat in Switzerland: the federal stations' programme (La selection du ble en Suisse: le programme des stations federales.). Revue Suisse d'Agriculture 35(4):169-180

Grieder C, Trachsel S, Hund A (2014) Early vertical distribution of roots and its association with drought tolerance in tropical maize. Plant Soil 377(1-2):295-308. https://doi. org/10.1007/s11104-013-1997-1

Holzkamper A, Fossati D, Hiltbrunner J, Fuhrer J (2015) Spatial and temporal trends in agro-climatic limitations to production potentials for grain maize and winter wheat in Switzerland. Reg Environ Change 15(1):109-122. https:// doi.org/10.1007/s10113-014-0627-7

Hund A, Ruta N, Liedgens M (2009) Rooting depth and water use efficiency of tropical maize inbred lines, differing in drought tolerance. Plant Soil 318(1-2):311-325. https:// doi.org/10.1007/s11104-008-9843-6

Hurd EA (1974) Phenotype and drought tolerance in wheat. Agr Meteorol 14(1-2):39-55. https://doi.org/10.1016/00021571(74)90009-0

Hussain M, Farooq S, Jabran K, Ijaz M, Sattar A, Hassan W (2016) Wheat sown with narrow spacing results in higher yield and water use efficiency under deficit supplemental irrigation at the vegetative and reproductive stage. Agronomy Basel. https://doi.org/10.3390/ agronomy6020022

Incerti M, Oleary GJ (1990) Rooting depth of wheat in the Victorian Mallee. Aust J Exp Agric 30(6):817-824. https:// doi.org/10.1071/Ea9900817

IPCC (2013) Summary for policymakers. In: Climate change 2013: the physical science basis. contribution of working group I to the fifth assessment report of the intergovernmental panel on climate change. Cambridge University Press, Cambridge, United Kingdom and New York, NY, USA, p 1535. https://doi.org/10.1017/cbo9781107415324

Kirkegaard JA, Lilley JM (2007) Root penetration rate-a benchmark to identify soil and plant limitations to rooting depth in wheat. Aust J Exp Agric 47(5):590-602. https:// doi.org/10.1071/EA06071

Krizek DT, Carmi A, Mirecki RM, Snyder FW, Bunce JA (1985) Comparative effects of soil-moisture stress and restricted root zone volume on morphogenetic and physiological-responses of soybean [Glycine-Max (L) Merr]. J Exp Bot 36(162):25-38. https://doi.org/10.1093/Jxb/36. 1.25

Lancashire PD, Bleiholder H, Vandenboom T, Langeluddeke P, Stauss R, Weber E, Witzenberger A (1991) A uniform decimal code for growth-stages of crops and weeds. Ann Appl Biol 119(3):561-601. https://doi.org/10.1111/j.17447348.1991.tb04895.x

Lupton FGH, Oliver RH, Ellis FB, Barnes BT, Howse KR, Welbank PJ, Taylor PJ (1974) Root and shoot growth of semi-dwarf and taller winter wheats. Ann Appl Biol 77(2):129-144. https://doi.org/10.1111/j.1744-7348.1974. tb06881.x 
Lynch JP (2007) Rhizoeconomics: the roots of shoot growth limitations. HortScience 42(5):1107-1109

Malik RS, Dhankar JS, Turner NC (1979) Influence of soilwater deficits on root-growth of cotton seedlings. Plant Soil 53(1-2):109-115. https://doi.org/10.1007/Bf02181885

Manschadi AM, Christopher J, Devoil P, Hammer GL (2006) The role of root architectural traits in adaptation of wheat to water-limited environments. Funct Plant Biol 33(9):823-837. https://doi.org/10.1071/Fp06055

MeteoSchweiz (2016) Climate normals Zürich/Affoltern. Reference period: 1981-2010. Federal Office of Meteorology and Climatology MeteoSwiss

Mori M, Inagaki MN, Inoue T, Nachit MM (2011) Association of root water-uptake ability with drought adaptation in wheat. Cereal Res Commun 39(4):551-559. https://doi. org/10.1556/Crc.39.2011.4.10

Oberholzer S, Prasuhn V, Hund A (2017) Crop water use under Swiss pedoclimatic conditions-evaluation of lysimeter data covering a seven-year period. Field Crop Res 211:48-65. https://doi.org/10.1016/j.fcr.2017.06.003

Pace PF, Cralle HT, El-Halawany SHM, Cothren JT, Senseman SA (1999) Drought-induced changes in shoot and root growth of young cotton plants. J Cotton Sci 3:183-187

Poorter H, Buhler J, van Dusschoten D, Climent J, Postma JA (2012) Pot size matters: a meta-analysis of the effects of rooting volume on plant growth. Funct Plant Biol 39(10-11):839-850. https://doi.org/10.1071/FP12049

Qin XL, Niklas KJ, Qi L, Xiong YC, Li FM (2012) The effects of domestication on the scaling of below- vs. aboveground biomass in four selected wheat (Triticum; Poaceae) genotypes. Am J Bot 99(6):1112-1117. https://doi.org/10.3732/ ajb.1100366

Raziuddin Swati ZA, Bakht J, Farhatullah Ullah N, Shafi M, Akmal M, Hassan G (2010) In situ assessment of morphophysiological response of wheat (Triticum aestivum L.) genotypes to drought. Pak J Bot 42(5):3183-3195

Reyes A, Messina CD, Hammer GL, Liu L, van Oosterom E, Lafitte R, Cooper M (2015) Soil water capture trends over 50 years of single-cross maize (Zea mays L.) breeding in the US corn-belt. J Exp Bot 66(22):7339-7346. https://doi. org/10.1093/jxb/erv430

Schenk HJ, Jackson RB (2002) The global biogeography of roots. Ecol Monogr 72(3):311-328. https://doi.org/10. 1890/0012-9615(2002)072\%5b0311:TGBOR\%5d2.0. $\mathrm{CO} ; 2$

Sharp RE, Hsiao TC, Silk WK (1990) Growth of the maize primary root at low water potentials. 2. Role of growth and deposition of hexose and potassium in osmotic adjustment. Plant Physiol 93(4):1337-1346. https://doi.org/10.1104/ pp.93.4.1337

Siddique KHM, Belford RK, Tennant D (1990) Root:shoot ratios of old and modern, tall and semi-dwarf wheats in a mediterranean environment. Plant Soil 121:89-98
Subira J, Ammar K, Alvaro F, del Moral LFG, Dreisigacker S, Royo C (2016) Changes in durum wheat root and aerial biomass caused by the introduction of the Rht-B1b dwarfing allele and their effects on yield formation. Plant Soil 403(1-2):291-304. https://doi.org/10.1007/s11104015-2781-1

Sun Y, Solomon S, Dai A, Portmann RW (2007) How often will it rain? J Clim 20(19):4801-4818. https://doi.org/10.1175/ JCLI4263.1

Tennant D (1976) Wheat root penetration and total available water on a range of soil types. Aust $\mathrm{J}$ Exp Agric 16(81):570-577. https://doi.org/10.1071/Ea9760570

Tester M, Langridge P (2010) Breeding technologies to increase crop production in a changing world. Science 327(5967):818-822. https://doi.org/10.1126/science. 1183700

Waines JG, Ehdaie B (2007) Domestication and crop physiology: roots of green-revolution wheat. Ann Bot Lond 100(5):991-998. https://doi.org/10.1093/Aob/Mcm180

Wasson AP, Richards RA, Chatrath R, Misra SC, Prasad SVS, Rebetzke GJ, Kirkegaard JA, Christopher J, Watt M (2012) Traits and selection strategies to improve root systems and water uptake in water-limited wheat crops. J Exp Bot 63(9):3485-3498. https://doi.org/10.1093/jxb/ers111

Wasson AP, Rebetzke GJ, Kirkegaard JA, Christopher J, Richards RA, Watt M (2014) Soil coring at multiple field environments can directly quantify variation in deep root traits to select wheat genotypes for breeding. J Exp Bot 65(21):6321-6349

Wojciechowski T, Gooding MJ, Ramsay L, Gregory PJ (2009) The effects of dwarfing genes on seedling root growth of wheat. J Exp Bot 60(9):2565-2573. https://doi.org/10. 1093/jxb/erp107

Xu CL, Tao HB, Tian BJ, Gao YB, Ren JH, Wang P (2016) Limited-irrigation improves water use efficiency and soil reservoir capacity through regulating root and canopy growth of winter wheat. Field Crop Res 196:268-275. https://doi.org/10.1016/j.fcr.2016.07.009

Ytting NK, Andersen SB, Thorup-Kristensen K (2014) Using tube rhizotrons to measure variation in depth penetration rate among modern North-European winter wheat (Triticum aestivum L.) cultivars. Euphytica 199(1-2):233-245. https://doi.org/10.1007/s10681-014-1163-8

Zhang XY, Pei D, Chen SY (2004) Root growth and soil water utilization of winter wheat in the North China Plain. Hydrol Process 18(12):2275-2287. https://doi.org/10.1002/hyp. 5533

Publisher's Note Springer Nature remains neutral with regard to jurisdictional claims in published maps and institutional affiliations. 